ing countries. US foundations led the way in supporting private-public partnerships on key research and innovationsparticularly to tackle infectious diseases in developing countries. The need for action on climate change is also leading to new dialogues to support research and innovation in developing countries. The Department for International Development in the United Kingdom was one of the first official donors to articulate a policy to emphasize the funding need for research and innovation in international development.

International research collaboration has entered an era in which networking has a direct economic significance. Some governments are already beginning to pay a premium to become hubs in global excellence networks. The question is whether these developments will produce significant changes in the world's research capacity. Will these reforms yield new centers of excellence? Will one approach be more successful than others in creating effective networks? Finally, will these trends create capacity building for research in developing countries or just more research relevant to developing countries? Only time will tell us the true answers to these questions, but it is worth paying attention to these emerging trends.

\section{International Student Mobility and the United States: The 2007 Open Doors Survey}

\section{Patricia Chow and Rachel Marcus}

Patricia Chow is Research Manager and Rachel Marcus is Research Officer, Institute of International Education. E-mail: iieresearch@iie.org. More information about the Open Doors survey can be found at: http://opendoors.iietnetwork.org.

Tn 2005, more than 2.7 million students were pursuing 1 transnational higher education-a 47 percent increase over the 2000 figure of I.7 million students. A concurrent increase has occurred in the number of students seeking an international education in nontraditional destinations in Asia, Africa, and Latin America. Several countries in these regions have positioned themselves as key actors in the global economy, attracting more students to their shores. Despite these developments, the United States continues to be the top host country for students seeking higher education abroad. In 2006, the United States attracted 30 percent of internationally mobile students among the leading eight host countries (Australia, Canada, China, France, Germany, Japan, and the United Kingdom).
This article draws upon key findings from the International Student Census of the recent Open Doors 2007: Report on International Educational Exchange to describe the current international student population in the United States and to examine the future trends in international enrollment. The Institute of International Education (IIE) has collected data on international student enrollment in the United States since I9I9 and in the form of the Open Doors survey since I954. Annually, Open Doors surveys approximately 3,000 regionally accredited US higher education institutions on aspects of international educational exchange. The 2007 survey reported 582,984 international students studying in the United States

In 2005, more than 2.7 million students were pursuing transnational higher education-a 47 percent increase over the 2000 figure of 1.7 million students.

during the 2006/07 academic year-a 3 percent increase over the previous year and the first significant increase in total international student enrollment since 200I/02. In addition, the number of new international students-those enrolling at a US higher education institution for the first time-increased by Io percent, building upon the 8 percent increase seen in 2005/06.

\section{ORIGINS}

Asia remains the largest sending region, accounting for 59 percent of total US international enrollments. The number of students from Asia increased by 5 percent this year, driven by increases from the top two sending places: India (10\% increase) and China ( $8 \%$ increase). For the seventh consecutive year, India remained the leading place of origin of international students in the United States, with 83,833 students. China remained in second place, with 67,723 students and the Republic of Korea in third place, with 62,392 students.

Turning to other regions, in $2006 / 07$ we saw a 25 percent increase in the number of students from the Middle East (to 22,32I students), largely due to the I29 percent increase in student numbers from Saudi Arabia (to 7,886 students) - the result of a large Saudi Arabian government scholarship program launched in 2005. Enrollments from Latin America remained steady in 2006/07, with Mexico sending the most students from the region $\left(\mathrm{I}_{3}, 826\right)$. Kenya, with 6,349 students, was the only African country in the top 20 places of origin this year. The number of international students from Europe and Oceania declined in $2006 / 07$, to $82,73 \mathrm{I}$ and 4,300, respectively. Europe and Oceania are the only two world regions where the number of US students studying abroad in the region exceeds the number of students from the region studying in the United States. 


\section{Student Profile and Fields of Study}

Over the past 30 years, Open Doors data have indicated small but significant shifts in the demographics of international students. In $2006 / 07,45$ percent of international students in the United States were female, a I4 percent increase from the I976/77 figure of 3I percent. Also, a larger proportion of international students were single in $2006 / 07$ (87\%), compared to 30 years ago $(74 \%)$.

As has been the case since 200I/02, international graduate students outnumbered international undergraduate students in 2006/07. Forty-five percent of international students were graduate students, 4I percent undergraduates, and I4 percent nondegree/certificate students or students on optional practical training.

\section{As has been the case since 2001/02, international graduate students outnumbered international undergraduate students. Forty-five percent of inter- national students were graduate students.}

Business and management remain the leading field of study for international students, with i 8 percent of the total, followed by engineering with 15 percent. These two fields have been the most popular fields of study for international students over the past five years. International students in the United States have a particularly large presence in sciences and engineering: in 2006, non-US citizens earned 45 percent of all doctorates in the science, technology, engineering, and mathematics fields, and accounted for over half of all doctorate recipients in the fields of engineering, computer science, mathematics, and physics (National Science Foundation, $2007<$ www.nsf.gov>).

\section{Destinations}

International students were enrolled in all 50 US states in $2006 / 07$, highly concentrated in certain states and institutions. The 156 US campuses that enrolled (each) over I,000 international students, accounted for 58 percent of total international student enrollment. The top host states are also home to many of the top host institutions. Colleges and universities in California enrolled the largest number of international students $(77,987$, or $13 \%$ of the total), followed by New York $(65,884$ students, or II percent of the total). New York City was the leading metropolitan area, with 5I,973 students, followed by Los Angeles, with 35,870 international students. Students tend to cluster in areas with geographic and linguistic similarities to their home country, as well as an area with a large student or immigrant population from their home country.

\section{Future Trends in InTERnational StUdent EnROLlment}

These Open Doors findings, supported by similar data collected by the Council of Graduate Schools and other surveys, suggest that the number of international students in the United States has rebounded and that the United States has not lost its attraction as a destination of choice for international students. In addition to providing high-quality teaching, the American higher education system is also esteemed throughout the world because of the availability of advanced technological facilities and extensive support for basic and applied research.

Meanwhile, US institutions have stepped up recruitment of international students and adjusted their application procedures and admissions timetables to accommodate the lead time needed for visa approval. These university-level efforts have been complemented by the US Department of State's steps to streamline the visa application and approval process and to promote the US as a welcoming place for international students.

While the results of these efforts by government and academia appear to be turning the tide, more comprehensive steps need to be taken to ensure that this trend continues. Other countries have also intensified efforts to attract international students, eliminating visa barriers and strengthening their graduate programs, especially in the sciences and engineering. Although the falling dollar may provide some relief, tuition costs in the United States continue to rise, ranging from an increase of 6.6 percent for public universities, to 4.2 percent for public two-year institutions. With the financial burden largely falling upon individuals and their families $162 \%$ of international students use personal/family funds to pay for

The number of international students in the United States has rebounded and that the United States has not lost its attraction as a destination of choice for international students.

their US education), it remains to be seen whether these increases will affect students' decisions to study in the United States. Widely disseminating information on financial resources and expanding financing options may help to alleviate the burden.

Authors' Note: The Open Doors Project has received support from the Bureau of Educational and Cultural Affairs of the US Department of State since the early I970s. The opinions expressed in this article are entirely those of the authors.

Visit our website for downloadable back issues of International Higher Education and other publications and resources at http://www.bc.edu/cihe. 